\title{
Sustainable food systems: building resilience for urban communities
}

\author{
S. R. Raftery \& R. C. Miner \\ Advanced Energy Growing ${ }^{\mathrm{TM}}$, USA
}

\begin{abstract}
The current food system is dependent upon the prevailing industrial (rural) farming system that rests upon unlimited access to fossil fuel/energy, fresh water, land, plus relatively stable climates. In the twenty-first century, all of these resources are in steep decline and yet the demand for food is growing exponentially due to rising standards of living and growing urban populations. With the increasing affluence of consumers globally, along with the increase in population, the need for increases in food production continues to intensify. The possibilities for creating an ecologically sustainable, new urban food production system are limited only by our imaginations. If the focus is the growing of fresh food, locally/regionally, year round, the opportunities are huge. This paper explores the principles of sustainable food systems, and how these principles can be used to create a new, ecologically friendly, urban/periurban, knowledgebased, twenty-first century food production system.

Keywords: urban agriculture, sustainable agriculture, food system, urban food production.
\end{abstract}

\section{Introduction}

With the convergence of the dwindling availability of natural resources (energy, land, fresh water), along with extreme weather occurrences and an ever growing global population, there is a need to create a new food system that includes urban agriculture.

The social constructs defining urban and rural have long separated two inexorably linked communities. Westernized urban dwellers have, with each successive generation of urban living, become more disconnected from the land and the food it produces. Until recently, with the local food movement, most 
consumers gave little thought to where their food was grown or processed. Today, however, “...the landscape is changing. There is a blurring of urban-rural distinction" [1]. Food production is no longer an exclusively rural endeavor. Whether people live in rural or urban areas, or in developed or developing nations, there must be a fundamental overhaul of how and where food is grown and distributed in order to address the changes in natural resources, weather patterns and population.

"Urban agriculture [2] must be viewed as the producer, processor and market for food, plant- and animal-sourced pharmaceuticals, fiber, and fuel on land and water dispersed throughout the urban and peri-urban areas, usually applying intensive production methods." Rather than replicate rural-based agriculture, cities must begin to design an urban model. This new urban model requires the integration of growing food into the urban economic and ecological systems [3]. This new model must be created from a technological viewpoint that mimics high tech start-ups, not based on a nostalgic agrarian mindset. Open-space, community gardens, and agrarian urbanism are all quite interesting, yet they do not factor in the need for fresh food not just seasonally, but year round.

An important demographic shift in the world's population took place on May 23, 2007, when, for the first time, more people lived in urban/metropolitan areas than in rural communities. The distinctions of city, suburban, periurban, and rural have resulted in a more heterogeneous entity given access to technologies, the Internet, and interaction with the global economy [4].

While other distinctions pertaining to the urban-rural dichotomy are fading, the spatial distribution of where food is grown seems to endure. It is not possible to grow grain (commodity) crops in an urban setting on the scale needed to be commercially viable. However, the potential exists to grow fresh foods (vegetables and fruits) in sufficient amounts to create more resilient food sheds in and around major urban communities. Now is the time to shift fresh food production to metropolitan and periurban regions, not just seasonally, but all year round. To understand why this shift needs to occur, one must first understand the current food system.

\section{The current food system}

Our current food system is dependent upon the prevailing rural industrial farming system that rests upon relatively stable climates in addition to the unlimited availability of:

- cheap energy,

- $\quad$ surplus fresh water, and

- land.

In the twenty-first century, all of these factors are in steep decline and yet the demand for food is growing exponentially due to rising standards of living and population increases. One of the largest obstacles to local/regional food production is the prevailing food system itself. The current food industry and the global shipping (logistics) industries prefer the status quo [5]. Changing this will 
require a fundamental shift in where and how food is grown in the twenty-first century.

It is time for a new, ecologically friendly, knowledge-based, food production system that includes:

- application of renewable energy sources,

- markedly reduced water consumption and increased water conservation,

- $\quad$ use of marginal land to expand productivity, and

- mitigation of climatic influences on the production of food.

Building regional food resilience would provide a viable alternative to the current food system. One can read any number of the recent publications on food and food systems, and find a call for building new ways of growing and delivering food to the consumer in order to address one or more of the above factors. In addition, there are other concerns regarding our current food system that negatively affect not only our food production, but also our environment and our health. "Although U.S. farms have provided growing supplies of food and other products, they have also been major contributors to global greenhouse gases, biodiversity loss, natural resource degradation, and public health problems" [6].

Table 1 breaks down four primary limitations of the existing food production/industrial farming sector of the United States economy: energy, water, land, and weather conditions.

Table 1: $\quad$ Current state of the U.S. industrial agriculture.

\begin{tabular}{|c|c|}
\hline Energy/Fossil Fuels & Fresh Water \\
\hline $\begin{array}{l}\text { The U.S. spends approximately } \$ 700 \\
\text { billion per year on fossil fuels } \\
19 \% \text { of all fossil fuels is used to } \\
\text { grow, process, and transport food to } \\
\text { both the U.S. and global } \\
\text { communities }\end{array}$ & $\begin{array}{l}\text { Fresh water is a non-renewable } \\
\text { resource } \\
3 \% \text { of the water on Earth is fresh } \\
\text { Agriculture/food production uses } \\
80 \% \text { of the available fresh water } \\
\text { annually }\end{array}$ \\
\hline Land & Weather \\
\hline $\begin{array}{l}\text { Arable farmland is a finite resource } \\
\text { The U.S. loses one acre of farmland } \\
\text { each minute } \\
\text { Our fresh food production is } \\
\text { increasingly in the path of urban } \\
\text { development, this encroachment } \\
\text { places fresh food production in peril. }\end{array}$ & $\begin{array}{l}\text { Of } 950 \text { natural disasters in } 2010,90 \% \\
\text { were related to extreme weather } \\
\text { incidents } \\
\text { Meteorological calamities are } \\
\text { becoming increasingly common, } \\
\text { further disrupting traditionally grown } \\
\text { food supplies. }\end{array}$ \\
\hline
\end{tabular}




\section{Creating a diverse, resilient urban food system}

Urban agriculture is not new to many metropolitan regions of the globe, yet the revival of growing in metropolitan areas in the United States has proposed challenges to local and regional governmental agencies. "Renewed interest in the relation of food production to urban growing has been made possible by increased public literacy about food and forms of industrial food production and distribution that characterize globalization" [7]. U.S. consumers' interest in knowing where their food is grown, along with the desire to decrease both our dependency on fossil fuels (transportation costs) and our carbon footprint, all contribute to the heightened interest in forming local food councils, establishing farmers markets, and supporting local growers. Yet, many of these solutions are seasonal at best, and available to a relatively small subset of the metropolitan population.

There is a growing acceptance that the structures and function of cities must change rapidly to respond to various drivers, e.g. resource scarcity, population pressure (urbanization) and climate change [8]. Moving beyond seasonal growing, to build long-lasting food system resilience will require building new food growing systems, and thus create year-round jobs (i.e., a new twenty-first century grower/farmer), and reduce the economic leakage that currently has monetary benefits flow to distant regions for the production and processing of food products. The global food system will continue to exist because there are food products that can only be grown in certain geographic regions (e.g., coffee, tea, exotic fruits) or on large expanses of land (e.g., grains). The goal is not to create food shed self-sufficiency (i.e., only what a community can grow locally), but rather to create food shed resilience, which is the ability to grow enough to provide a back-up should there be any disruption in the current industrial food system model.

\section{What is a sustainable/resilient food system?}

The last decade has seen a great deal of hype over the terms "sustainable" and "green" to the point where one must be very specific in defining and using these terms. The present industrial model of agriculture is not sustainable for all of the reasons stated earlier concerning the depletion of natural resources. However, a new definition for a sustainable food system has yet to be created.

Until consumers understand where their food comes from, we will continue to live in a world in which the landscape that produces our food is invisible, and disconnected from our consumers in our supermarkets [9]. This disconnect is a human construct, one which can be reversed. To date, the reversal efforts have been to form farmers markets, roof top gardens, community gardens, and Community Support Agriculture (CSA). While these are important, they could be likened to placing a bandage on a wound that needs a tourniquet. It is time to move food growing back into the view of the consumers. Connect the consumers to where and how their food is grown, and use their growing awareness to support the development of a new food system. 
Burke [9] goes on to state, "The industrial food system spends considerable time and money moving food around...the dualism that operates city and country in our culture resists the idea that food be produced where it is consumed... Should cheap supplies of fuel fail us, both growers and consumer will be harmed."

In the U.S., if the measure of sustainability is a balance of inputs and outputs to food production, it is hardly sustainable to expend eighty-seven calories of energy to transport one calorie of food from one coast (California) to another coast (New York). In addition, it is not just about energy, but also the use of fresh water.

Water receives little consideration in the costs of growing food. Yet, fresh water, unlike the ability to create alternative fuels, is a finite resource. Without fresh water, one cannot grow food or people. Annually, the current U.S. agricultural industry consumes $80 \%$ of all of the fresh water on the planet. Add to this, the food grown in this manner is shipped long distances; it is, in fact, water resources we are shipping (e.g. grain grown in the U.S. where water is plentiful, is then shipped to developing nations where water is scarce, thus even grain represents the shipping of water). For commodity crops, think of the water it took to produce two pounds of rice (792 gallons/3004 liters); or two pounds of beef (3,692 gallons/13,976 liters). In all, approximately 1,321 gallons of water (5,000 liters) is used per day to produce food for one person, using the Western standard diet of the developed world.

Even after food is grown, the last (and hidden) variable in the current food system is waste. Waste represents the loss of the input of energy/fossil fuels, water, and depletion of land fertility.

"Half the world's food is lost, wasted, or discarded along the chain from the farm to shop to consumer to dump" [10]. It is estimated that $17 \%$ of all the waste placed in landfills annually is food waste [11]. This is not just a loss of food, but likewise, energy, water, and labor costs, not factoring in the loss of crops in extreme weather incidents. This simply is not a sustainable model of food production or consumption. Will Allen [12], a food activist in Milwaukee, Wisconsin, believes that waste can be reduced if the long chains in the food system were broken by the availability of food from the local community.

Peemoeller [13] contends that in the U.S., we accept the abundance of food available in the supermarkets as inevitable, and yet this is a false reality. Access to inexpensive food has long been a norm for the U.S. consumer, yet food prices have never reflected the cost of production, processing, and transportation. Each food choice is an environmental act, as well as one of personal preference. "A food system will only be sustainable as long as it can maintain its ability to feed people without depleting natural resources" [14]. Without standard definitions of urban agriculture, sustainable agriculture, and food access/resilience, the current food system is largely unchallenged. Perhaps the answers to creating a new food system must be found in how the entire spectrum of consumers and political entities from urban (core), suburbia, periurban, and rural communities address these issues, not in the current industrial agriculture sector. 
Table 2, Characteristics of a Sustainable Food Systems for Urban/Metro Regions, outlines the natural recourses and weather advantages if we but take into consideration a new twenty-first century food system based upon a recent study by the American Planning Association (APA) [15]. It is at the nexus of energy, water, land, and increasing extreme weather conditions lays a potential new and creative approach to feeding the metropolitan communities of the twenty-first century. This new system can and must co-exist with traditional agricultural practices even though other food production sectors (primarily commodity growers) face an uncertain future given their dependence upon fossil fuels. Reshaping the part of the food system that is flexible and malleable to new growing techniques will reduce the dependency of fresh food upon fossil fuels.

Table 2: Characteristics of a sustainable food system for urban/metro regions.

\begin{tabular}{|c|c|}
\hline $\begin{array}{c}\text { Using Renewable Energy } \\
\text { Sources }\end{array}$ & $\begin{array}{c}\text { Reducing Water Consumption and } \\
\text { Increasing Water Conservation }\end{array}$ \\
\hline $\begin{array}{c}\text { Use biomass/waste-to- } \\
\text { energy to grow food; } \\
\text { provide resulting } \\
\text { compost from the } \\
\text { process for local use }\end{array}$ & $\begin{array}{c}\text { Collect and filter storm water to } \\
\text { conserve water }\end{array}$ \\
$\begin{array}{c}\text { Participate in resource } \\
\text { sharing among/between } \\
\text { other regional businesses } \\
\text { committed to reuse of } \\
\text { resources }\end{array}$ & $\begin{array}{c}\text { Use advanced filtering and } \\
\text { recycling }\end{array}$ \\
\hline $\begin{array}{l}\text { Developing Supportive Land } \\
\text { Use Policies }\end{array}$ & $\begin{array}{c}\text { Apply technologies to reduce the } \\
\text { grow fresh food }\end{array}$ \\
\hline $\begin{array}{l}\text { Target the use of marginal } \\
\text { lands in urban, suburban, } \\
\text { periurban and rural } \\
\text { communities to grow } \\
\text { food, thus supporting } \\
\text { farmland preservation } \\
\text { and conservancy of } \\
\text { natural habitats }\end{array}$ & $\begin{array}{c}\text { Mitigating Extreme Weather Impact } \\
\text { Create controlled environments } \\
\text { that can withstand extreme } \\
\text { weather fluctuations, and } \\
\text { minimize the impact of weather } \\
\text { on growing crops }\end{array}$ \\
\hline
\end{tabular}


In addition to the four areas where change must be made (energy, water, land, and mitigation of extreme weather conditions), Peemoeller [15] likewise outlined other benefits to creating sustainable urban food systems:

- creating green-collar jobs, not just seasonally but year round,

- keeping food dollars in the metro/region areas, to create economic multipliers,

- creating supply chain opportunities, and

- striving for LEED compliance, adapting food production to sustainable structures for the long-term, creating regional food systems, not passing fads.

\section{Cities moving forward to build food resilience}

Two reports in the fourth quarter of 2011 gave recognition of how metropolitan regions can, and will, begin to address the need to grow food in the greater metropolitan areas $[16,17]$. Both speak to the need for policy changes and, in the latter report, how building relationships with the greater ecological region, rural, periurban, suburban, and core urban, creates a better quality of life for all [18].

It is not a question of if U.S. greater metropolitan regions engage in greater activities in urban agriculture, but when. People will still need to eat even within the constraints of limited natural resources and weather instability coupled with population growth. The question remains, can we begin to make the required shifts in how and where food is grown (i.e., closer to the consumer) before political or natural disasters interrupt (negatively) the current industrial food system?

\section{References}

[1] Champion, A.G. \& Hugo, G., New forms of urbanization: Beyond the urban-rural dichotomy. Ashgate Publishing Company: Burlington, Vermont, p.3, 2004.

[2] Pearson, L.J., Pearson, L., \& Pearson, C. J., (2010). Sustainable Urban Agriculture: Stocktake and Opportunities. International Journal of Agricultural Sustainability 8 (1 \& 2), pp. 7-19, 2010.

[3] Mougeot, L. J. A., Urban Agriculture: Definition, Presence, Potentials and Risks, www.trabajopopular.org.ar/material/Theme1.pdf].

[4] Frey, W. H., The fading of city-suburb and metro-nonmetro distinctions. New Forms of Urbanization: Beyond the Urban-Rural Dichotomy, A.G. Champion \& G. Hugo, Ashgate Publishing Company: Burlington, Vermont, pp. 6-88, 2011.

[5] Tumber, C., Small, Gritty, and Green: The Promise of America's Smaller Industrial Cities in a Low-Carbon world, Massachusetts Institute of Technology: Cambridge, MA, 2012.

[6] Reganold, J.P. et al. Transforming U.S. Agriculture. Science, vol. 332, pp. 670-671, 2011. 
[7] Waldheim, C., Notes toward a history of agrarian urbanism. Bracket: On farming, ed. M. White and M. Przbylski, Actar: New York, pp. 18-22, 2011.

[8] Van Ginkel, H., Urban Future. Nature 456, pp. 32-33, .2008.

[9] Burke, E., Farm plus: hybrid agricultural landscapes. Bracket: On farming, ed. M. White and M. Przbylski, Actar: New York, pp. 88-91, 2011.

[10] London Evening Standard, 2-21-2011.

[11] Stuart, T., Waste: Uncovering the Global Food Scandal, W.W. Norton \& Company: New York, New York, 2009.

[12] Duany, A., Garden cities: Theory \& practice of agrarian urbanism, The Prince's Foundation for the Built Environment: London, England, 2011.

[13] Peemoeller, L. Sustainable Food Systems, (Chapter 9). Sustainable and resilient communities, ed. Coyle, S.J. \& Duany, A., John Wiley and Sons: Hoboken, NJ, 2011.

[14] Coyle, S. J., \& Duany, A., Sustainable and resilient communities. John Wiley and Sons: Hoboken, NJ, 2011.

[15] Peemoeller, L. Sustainable Food Systems, (Chapter 9). Sustainable and resilient communities, ed. Coyle, S.J. \& Duany, A., John Wiley and Sons: Hoboken, NJ, 2011.

[16] Goldstein, M., Bellis, J., Morse, S., Myers, A. \& Ura, E., Urban Agriculture: A Sixteen City Survey of Urban Agriculture Practices Across the Country, Turner Environmental Law Clinic: Emory University, 2011.

[17] New York City Council. (2011). FoodWorks: A vision to improve NYC's food system. New York City Council, Christine C. Quinn, Speaker, 2008.

[18] Tumber, C., Small, Gritty, and Green: The Promise of America's Smaller Industrial Cities in a Low-Carbon world, Massachusetts Institute of Technology: Cambridge, MA, 2012. 